\title{
Quantitative assessment of phytochemicals and nutritional potential of leaves and seeds of Cleome viscosa from Abakaliki, Nigeria
}

\author{
Uraku, A. J.* and Uraku, O. H. \\ Department of Biochemistry, Ebonyi State University, PMB 053 Abakaliki, Ebonyi State, Nigeria. \\ *Corresponding author: Email: urakuaj@yahoo.com. Tel: +234-8068073037.
}

Copyright (C) 2018 Uraku and Uraku. This article remains permanently open access under the terms of the Creative Commons Attribution License 4.0, which permits unrestricted use, distribution, and reproduction in any medium, provided the original work is properly cited.

Received 12th May, 2017; Accepted 6th November, 2017

\begin{abstract}
The phytochemicals and nutritional potential of the leaves and seeds of Cleome viscosa were assessed by determining phytochemical, proximate, vitamin and mineral compositions. Results indicate alkaloid contents of the leaves and seed as 0.21 and $6.12 \mathrm{mg} / 100 \mathrm{~g}$ respectively. Other findings are flavonoids 0.02 and 0.45 , tannins 0.08 and 1.18, phenol 0.50 and 0.04 , steroids 2.66 and 0.37 , saponon 0.35 and 2.77 , oxalates 0.01 and 0.66 , cyanide 0.61 and $1.07 \mathrm{mg} / 100 \mathrm{~g}$ for the leaves and seed respectively. Also, the results indicate carboydrate contents of the leaves and seed as 56.44 and $40.00 \%$ respectively. Others include: Crude Protein 13.52 and 6.41, Fats 4.29 and 1.32, Crude fibre 12.52 and 27.35, Ash 4.96 and 13.10, Moisture 8.26 and 11.83\%. Vitamin content indicate the order vit $A<v i t B_{9}<v i t E<$ vit $C<$ vit $B_{3}<$ vit $B_{2}<$ vit $B_{5}<$ vit $B_{1}$ in the leaves while that of seeds were vit $B_{9}<$ vit $A<v$ it $C<$ vit $B_{3}<$ vit $B_{1}<$ vit $B_{2}<$ vit $B_{5}<$ vit $E$. Mineral analysis revealed the order $\mathrm{P}<\mathrm{K}<\mathrm{Ca}<\mathrm{Na}<\mathrm{Mg}<\mathrm{Fe}<\mathrm{Zn}$ in the leaves and $\mathrm{P}<\mathrm{K}<\mathrm{Na}<\mathrm{Mg}<\mathrm{Ca}<\mathrm{Fe}>\mathrm{Na}<\mathrm{Zn}$ in the seeds. Phytochemical analysis revealed high oxalate, phenol but low sterol content in the studied plant materials. Oxalate and cyanide levels were higher in the seeds compared to the leaves. These results suggest that Cleome viscosa is awfully nutritive despite the presence of some anti-nutrients like oxalate and cyanide.
\end{abstract}

Key words: Cleome viscosa, nutritional composition, phytochemical.

\section{INTRODUCTION}

The involvement of diverse plant sort to health-care services can not be over-emphasized. These plants have been sources of numerous phytochemicals and nutrients in capricious magnitude. Phytocompounds are essential in drug breakthrough and their functions are given ample thoughtfulness in human body. This is because dearth of some nutrients in the body can lead to prime and resultant diseases. Alots of these plants are used to treat and prevent some of these diseases. A good number of these plants have had their phytochemical and nutritional composition analysed while others have not. There is a paucity of information if any in the literature on the phytochemical and nutritional compositions of Cleome viscosa.

Cleome is a genus of flowering plants in the family
Cleomaceae. This genus had previously been placed in the family Capparaceae, until DNA studies found that Cleomaceae genera are more closely related to Brassicaceae than Capparaceae (Stevens, 2012). The family Cleomaceae is of about 12 genera and 250 species are distributed in tropical and warm temperate regions (The Plant List, 2013). Members of this family are herbaceous or shrubby plants with palmately compound leaves (Stevens, 2012). C. viscosa is a native to Asia, but now has a pantropical distribution and is naturalized in tropical and subtropical regions in Asia, Africa, the Americas, and Oceania (Acevedo-Rodriguez and Strong, 2012; Flora of China Editorial Committee, 2015; PIER, 2015; USDA-ARS, 2015). According to Flora of China Editorial Committee (2015), C. viscosa is a fast-growing 


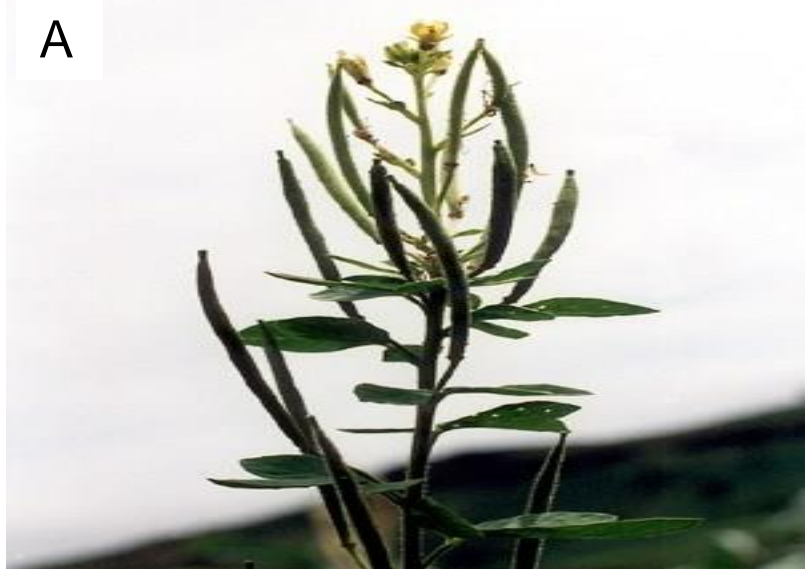

Figure 1. Leaves (A) and Seeds (B) of Cleome viscosa.

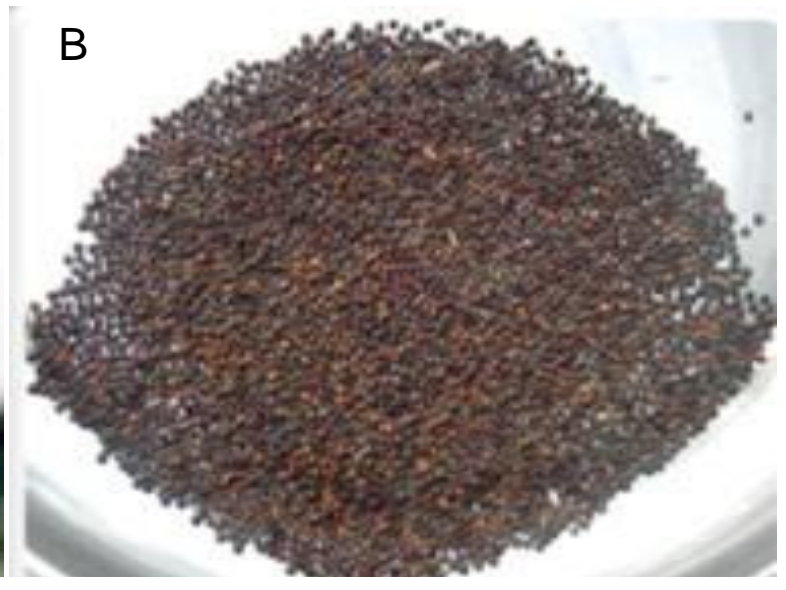

annual herb of humid and warm habitats that grow up to $160 \mathrm{~cm}$ tall. It is commonly found growing as a weed in disturbed sites, gardens, rice paddies, pastures, orchards, abandoned lands, and along roadsides (Flora of China Editorial Committee, 2015; PROTA, 2015).

In tropical Africa, C. viscosa is occasionally used as a leaf vegetable. The bitter leaves are eaten fresh, dried or cooked. In India, the seeds which have a pleasant flavour are used as a condiment substitute for mustard seed and cumin in the preparation of pickling spices, sausages, vegetables, curries and pulses. In Sumatra, the dried and powdered leaves and seeds are added to tobacco to enhance its narcotic properties (Windadri, 2001). In Asia, the leaves and seeds are used medicinally to treat infections, fever, rheumatism and headaches (PROTA, 2015). In Ebonyi State Nigeria, C. viscosa is used as mosquito repellent by the rural dwellers. According to them, it is done by detaching the stem from the whole plant and allows to wither for them to repel mosquito.

Notwithstanding the popular uses of $C$. viscosa, there is little or no information on phytochemical, proximate, vitamin and mineral contents in literature. Hence, this research was aimed at studying the compositions of phytochemical, proximate, vitamin and mineral of $C$. viscosa leaves and seeds that make them constructive in curing some ailments and in use as food.

\section{MATERIALS AND METHODS}

Fresh leaves and seeds (Figure 1a and b) of Cleome viscosa were gotten from Democracy Estate in Abakaliki Local Government Area of Ebonyi State, Nigeria. The plant samples were identified and authenticated by Dr. Nnamani, K., a taxonomist in the Department of Biological Science, Biology Option of Ebonyi State University, Abakaliki, Ebonyi State, Nigeria.
The leaves and seeds of cleome viscosa were sorted, washed thoroughly with distilled water to remove dirt and debris, cut into smaller pieces before it was shade dried at room temperature $\left(28 \pm 3^{\circ} \mathrm{C}\right)$. After drying, the leaves and seeds were ground separately into a fine powder using a manual grinder, sieved and stored in an air-tight contained, kept in a desiccators until analyzed.

\section{Quantitative phytochemical analysis}

The method of AOAC (2004) as described Akubugwo et al. (2007) was adopted to assay for the quantitative phytochemicals.

\section{Measurement of proximate parameters and selected vitamins and minerals}

The proximate and selected vitamin compositions were determined by the metod of Association of Official Analytical Chemist (AOAC.), (2004) while minerals were determined using Atomic Absorption Spectrophotometer (AAS).

The leaves and seeds of Cleome viscosa were analyzed for phytochemical contents. The results of phytochemicals of the leaves and seeds of Cleome viscosa presented in Table 1 showed that phenol and steroid contents were higher in the leaves relative to the seeds. According to the report of Akubugwo et al. (2007) on nutritional potential of the leaves and seeds of Black

\section{Preparation of plant material}

\section{RESULTS AND DISCUSSION}


Table 1. Phytochemical compositions of Cleome viscosa in leaves and seeds.

\begin{tabular}{lcc}
\hline Phytochemicals & Composition in $\mathbf{~} \mathbf{g} / \mathbf{1 0 0} \mathbf{g}$ of leaves & Composition $\mathbf{~} \mathbf{~} \mathbf{g} / \mathbf{1 0 0 g}$ of seeds \\
\hline Alkaloids & $0.21 \pm 0.01$ & $6.12 \pm 0.02$ \\
Flavonoids & $0.02 \pm 0.00$ & $0.45 \pm 0.02$ \\
Tannins & $0.08 \pm 0.00$ & $1.18 \pm 0.01$ \\
Phenola & $0.50 \pm 0.80$ & $0.04 \pm 0.01$ \\
Steroids & $2.66 \pm 0.28$ & $0.37 \pm 0.01$ \\
Saponons & $0.35 \pm 0.00$ & $2.77 \pm 0.02$ \\
Oxalates & $0.01 \pm 0.02$ & $0.66 \pm 0.14$ \\
Cyanides & $0.61 \pm 0.01$ & $1.07 \pm 0.00$ \\
\hline
\end{tabular}

Values are mean \pm standard deviation of the triplicate determinations.

Table 2. Proximate compositions of Cleome viscosa in leaves and seeds.

\begin{tabular}{lcc}
\hline Parameters & Composition in percent of leaves & Composition in percent of seeds \\
\hline Carbohydrate & $56.44 \pm 0.07$ & $40.00 \pm 0.00$ \\
Crude Protein & $13.52 \pm 0.02$ & $6.41 \pm 0.01$ \\
Fat & $4.29 \pm 0.07$ & $1.32 \pm 0.01$ \\
Crude fibre & $12.52 \pm 0.14$ & $27.35 \pm 0.01$ \\
Ash & $4.96 \pm 0.00$ & $13.10 \pm 0.02$ \\
Moisture & $8.26 \pm 0.02$ & $11.83 \pm 0.02$ \\
\hline
\end{tabular}

Values are mean \pm standard deviation of the triplicate determinations.

Nightshade- Solanum nigrum L. Var virginicum, the leaves and seeds of Solanum nigrum L. Var virginicum had higher amounts of flavonoid, phenol, oxalate and cyanide compared to the leaves and seeds of Cleome viscosa while steroid and saponin contents of both leaves and seeds of cleome viscosa were higher to that of Solanum nigrum. Also, alkaloids and tannins content of the leaves of Cleome viscosa were lower compared to Solanum nigrum L. Var virginicum. Offor et al. (2015) revealed appreciable high levels of phytochemicals analyzed on leaves of Terminalia catappa which in disagreement with the result of this study. Though, the leaves and seeds contain relatively high levels of oxalate and cyanide, the processing methods prior to consumption which may include cooking reduces their final consumed amount.

Proximate contents as shown in Table 2 indicated that carbohydrate, crude protein and fats were of higher amounts in the leaves comparative to the seeds. The quantity of carbohydrate in the leaves and seeds of $C$. voscosa compared favorably with that of Solanum nigrum L. Var virginicum as asserted by Akubugwo et al. (2007). Similarly, the crude protein and fat contents of the leaves of Cleome viscosa compared favorably with the Solanum nigrum L. Var virginicum but disagreed with others while the seeds conflicted in general with all other proximate contents. The report of Igwenyi et al. (2017) on nutritional potential of Azadirachta indica seed revealed high concentrations of carbohydrate which aligned with the result obtained in this study. Conversly, the report of Igwenyi et al. (2017) was in divergence with the result obtained in concentrations of crude protein and fibre, fat, ash and moisture. Offor et al. (2015) on proximate and phytochemical analysis of Terminalia catappa leaves recorded high concentration of carbohydrate, moderate concentration of crude fibre and moisture and low concentration of ash. This report was in concurrence with the result of this study. The report of Uraku et al. (2016) on the assessment of nutritional value of culcasia scandens $p$. beauv leaves concurred with the result of the proximate analysis obtained in this research.

Table 3 showed the results of vitamin constituents. It posited that vitamin $A$ and $E$ were higher in the leaves than in the seeds. The leaves and seeds of Cleome viscosa had equal amounts of vitamin $B_{2}$ and $B_{5}$. Vitamin $\mathrm{A}$ and $\mathrm{B}_{9}$ contents of $C$. viscosa were higher in both leaves and seeds to that of Solanum nigrum while $\mathrm{B}_{1}, \mathrm{C}$ and $\mathrm{E}$ were lower in both leaves and seeds of $C$. viscosa. Uraku et al. (2016) on assessment of nutritional value of Culcasia scandens $p$. beauv leaves recorded high levels of vitamin A, B and low levels of vitamin C and other B vitamins. This report is in affirmation with the obtained result and disagreed with the quantity of vitamin C recorded.

The result of mineral contents of the leaves and seeds of Cleome viscosa as presented in Table 4 demonstrated 
Table 3. Vitamin compositions of Cleome viscosa in leaves and seeds.

\begin{tabular}{lcc}
\hline Vitamins & Composition in $\mathbf{~ g / 1 0 0 g}$ of leaves & Composition in $\mathbf{~ g / 1 0 0 g ~ o f ~ s e e d s ~}$ \\
\hline Vitamin $A$ & $104.60 \pm 0.00$ & $6.00 \pm 0.00$ \\
Vitamin $B_{1}$ & $0.07 \pm 0.00$ & $0.34 \pm 0.40$ \\
Vitamin $B_{2}$ & $0.13 \pm 0.00$ & $0.13 \pm 0.00$ \\
Vitamin $B_{3}$ & $0.17 \pm 0.00$ & $1.08 \pm 0.00$ \\
Vitamin $B_{5}$ & $0.12 \pm 0.00$ & $0.12 \pm 0.00$ \\
Vitamin $B_{9}$ & $18.13 \pm 0.02$ & $20.13 \pm 0.01$ \\
Vitamin $C$ & $0.28 \pm 0.00$ & $2.43 \pm 0.01$ \\
Vitamin $E$ & $1.04 \pm 0.00$ & $0.02 \pm 0,00$ \\
\hline
\end{tabular}

Values are mean \pm standard deviation of the triplicate determinations.

Table 4. Mineral compositions of Cleome viscosa in leaves and seeds.

\begin{tabular}{lcc}
\hline Minerals & Composition in $\mathbf{~} \mathbf{g} / \mathbf{1 0 0 g}$ of leaves & Composition in $\mathbf{~ g} / \mathbf{1 0 0 g}$ of seeds \\
\hline $\mathrm{Ca}$ & $42.74 \pm 0.21$ & $0.72 \pm 0.01$ \\
$\mathrm{Na}$ & $19.57 \pm 0.00$ & $10.44 \pm 0.02$ \\
$\mathrm{~K}$ & $392.00 \pm 0.00$ & $12.55 \pm 0.14$ \\
$\mathrm{Mg}$ & $13.54 \pm 0.08$ & $0.87 \pm 0.00$ \\
$\mathrm{P}$ & $450.13 \pm 0.20$ & $16.68 \pm 0.14$ \\
$\mathrm{Fe}$ & $8.24 \pm 0.00$ & $0.49 \pm 0.14$ \\
$\mathrm{Zn}$ & $1.81 \pm 0.00$ & $0.13 \pm 0.01$ \\
\hline
\end{tabular}

Values are mean \pm standard deviation of the triplicate determinations.

that all the selected elements analyzed were higher in the leaves compared to the seeds. $\mathrm{Ca}$ and $\mathrm{K}$ contents of $C$. viscosa were higer in the leaves comparable to Solanum nigrum but lower in the seeds of $C$. viscosa compared to Solanum nigrum. $\mathrm{Na}$ and $\mathrm{Zn}$ were higer in both leaves and seeds of $C$. viscosa similar to Solanum nigrum. $\mathrm{Mg}$ and $\mathrm{Fe}$ were lower in both leaves and seeds of $C$. viscosa to that of Solanum nigrum while $\mathrm{P}$ contents of Solanum nigrum compared favorably with that of $C$. viscosa. Igwenyi et al. (2017) recorded high concentrations of $\mathrm{P}$ and low concentrations of $\mathrm{Fe}$ and $\mathrm{Mg}$ which is in accordance with the result obtained in this work but in discrepancy with the concentrations of $\mathrm{Ca}$.

\section{Conclusions}

In précis, the leaves and seeds of $C$. viscosa contained substantial quantities of phytochemicals, proximate contents, vitamins and mineral elements but in variable amounts. Therefore, the plant is recommended as a cheap source of carbohydrate, protein, energy, vitamins and minerals.

\section{CONFLICT OF INTEREST}

The authors declare that they have no conflict of interest.

\section{REFERENCES}

Acevedo-Rodríguez, P., \& Strong, M. T. (2012). Catalogue of the Seed Plants of the West Indies. Smithsonian Contributions to Botany, Washington DC, USA, 98,1192.

Akubugwo, I. E., Obasi, A. N., Ginika, S. C. (2007). Nutritional Potential of the Leaves and Seeds of Black NightshadeSolanum nigrum L. Var virginicum from Afikpo-Nigeria. Pakistan Journal of Nutrition, 6(4), 323-326.

AOAC (2004). Official Method of Analysis of Association of Analytical Chemists", 15th Edition, Wishington DC, USA, Pp. 200-210.

Flora of China Editorial Committee (2015). Flora of China. St. Louis, Missouri and Cambridge, Massachusetts, USA: Missouri Botanical Garden and Harvard University Herbaria.

Igwenyi, I. O., Nchi, P. O., Okechukwu, U. P., Igwenyi, I. P., Obasi, D. C., Edwin, N., Uraku, A. J., Eze, A. C. (2017). Nutritional potential of Azadirachta indica seeds. Indo American Journal of Pharmaceutical Sciences, 4 (02), 477482.

Offor, C. E., Ugwu Okechukwu, P. C., Aja, P. M., Igwenyi, I. O. (2015). Proximate and phytochemical analysis of Terminalia catappa leaves. European Journal of Applied Sciences, 7(1), 9-11.

PIER (2015). Pacific Islands Ecosystems at Risk. Honolulu, USA: HEAR, University of Hawaii.

PROTA (2015). PROTA4U web database. Grubben GJH, Denton OA, eds. Wageningen, Netherlands: Plant Resources of Tropical Africa.

Stevens, P. F. (2012). Angiosperm Phylogeny website. Available 
at http://www.mobot.org/MOBOT/research/APweb/.

Thaman, R. R., Fosberg, F. R., Manner, H. I., Hassall, D. C. (1994). The flora of Nauru. Atoll Research Bulletin, 392,1223.

The Plant List (2013). The Plant List: a working list of all plant species. Version 1.1. London, UK: Royal Botanic Gardens, Kew.

Uraku, A. J., Igwenyi, I. O., Alum, E., Orji, O. U. (2016). Assessment of nutritional value of Culcasia scandens $P$. Beauv leaves. Advances in Biomedicine and Pharmacy, 3(2), 115-119.

USDA-ARS (2015). Germplasm Resources Information Network (GRIN). Online Database. Beltsville, Maryland, USA: National Germplasm Resources Laboratory.
USDA-NRCS (2015). The PLANTS Database. Baton Rouge, USA: National Plant Data Center.

Windadri, F. I. (2001). Cleome viscosa L. Record from Proseabase [ed. by Valkenburg, J. L. C. H. van IBunyapraphatsara, N.]. Bogor, Indonesia: PROSEA (Plant Resources of South-East Asia) Foundation. 